\title{
ALEXANDRIA
}

Revista de Educação em Ciência e Tecnologia

\section{RESIDUO DE FÁBRICA}

Hoy ha tosido mucho. Van dos noches que no puede dormir; noches fatales, en esa oscura pieza donde pasa sus más amargos días, sin quejarse.

El taller la enfermó, y así, vencida en plena juventud, quizá no sabe de una hermosa esperanza que acaricie sus largos pensamientos de incurable.

Abandonada siempre, son sus horas como su enfermedad: interminables. Sólo a ratos, el padre, se le acerca cuando llega borracho, por la tarde...

Pero es para decirle lo de siempre, el invariable insulto, el mismo ultraje: ile reprocha el dinero que le cuesta la llama haragana, el miserable!

Ha tosido de nuevo. El hermanito que a veces en la pieza se distrae jugando, sin hablarla, se ha quedado de pronto serio como si pensase...

Después se ha levantado, y bruscamente e se ha ido murmurando al alejarse, con algo de pesar y mucho de asco: - que la puerca, otra vez escupe sangre...

\section{Evaristo Carriego}

Disponível em:

http:/ / edant.clarin.com/diario/especiales/yrigoyen/textos/residuo.htm

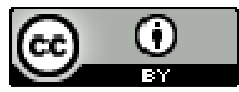

